\title{
Research
}

\section{A New Method for Estimating Insolation Based on PV-Module Currents in a Cluster of Stand-Alone Solar Systems}

\author{
Frans Nieuwenhout ${ }^{1 *, \dagger}$, Nico van der Borg ${ }^{1}$, Wilfried van Sark ${ }^{2}$ and Wim Turkenburg ${ }^{2}$ \\ ${ }^{1}$ Energy research Centre of the Netherlands, PO Box 1, 1755 ZG Petten, The Netherlands \\ ${ }^{2}$ Department of Science, Technology and Society, Copernicus Institute for Sustainable Development and Innovation, \\ Utrecht University, Heidelberglaan 2, 3584 CS Utrecht, The Netherlands
}

In order to evaluate the performance of solar home systems (SHSs), data on local insolation is a prerequisite. We present a new method to estimate insolation if direct measurements are unavailable. This method comprises estimation of daily irradiation by correlating photovoltaic (PV) module currents from a number of SHSs, located a few kilometres apart. The method was tested with a 3-year time series for nine SHS in a remote area in Indonesia. Verification with reference cell measurements over a 2-month period showed that our method could determine average daily irradiation with a mean bias error of 1.3\%. Daily irradiation figures showed a standard error of $5 \%$. The systematic error in this method is estimated to be around 10\%. Especially if calibration with measurements during a short period is possible, the proposed method provides more accurate monthly insolation figures compared with the readily available satellite data from the NASA SSE database. An advantage of the proposed method over satellite data is that irradiation figures can be calculated on a daily basis, while the SSE database only provides monthly averages. It is concluded that the new method is a valuable tool to obtain information on insolation when long-term measurements are absent. Copyright (C) 2007 John Wiley \& Sons, Ltd.

KEY WORDS: solar irradiation; insolation; monitoring

Received: 28 September 2006; Revised 15 November 2006

\section{INTRODUCTION}

$\mathrm{S}$ olar home systems (SHS) are becoming an increasingly popular means of rural electrification in developing countries. The potential market for SHS is huge, as currently about 2 billion people do not have access to electricity. Supply of electricity from SHS depends on maintenance of the systems. It was therefore disappointing to find through field surveys that only about $77 \%$ of the installed systems are still working a few years after installation. ${ }^{1}$ To study the effect of user behaviour on SHS performance, detailed system monitoring with data loggers is required, supplemented with information from technical system checks

* Correspondence to: Frans Nieuwenhout, Energy research Centre of the Netherlands, PO Box 1, 1755 ZG Petten, The Netherlands.

†E-mail: nieuwenhout@ecn.nl 
and questionnaires. Very few projects have been monitored at the required level of detail, and these were often pilot projects, such as Balde de Leyes in Argentina ${ }^{2,3}$ and Sukatani in Indonesia ${ }^{4}$.

With the objective to increase knowledge on user behaviour and quality issues in a large scale project, BPPT, the Indonesian Agency for the Assessment and Application of Technology and the Energy research Centre of the Netherlands ECN, have conducted detailed monitoring of recently installed SHSs over the period 2001-2003. In 2001, dataloggers were added to nine recently installed SHSs in Kolaka district, in the South-eastern part of the island of Sulawesi in Indonesia. About 1400 SHSs with $53 \mathrm{~W}_{\mathrm{p}}$ modules were installed in Kolaka district in 1997-2000. They were financed through a revolving fund from a previous, Australian Aid funded project with 36400 systems. $^{5}$ Preliminary results of the BPPT-ECN monitoring have been presented on different occasions. $^{6,7}$

For determining the performance of solar systems over a number of years, information on insolation is required. Local measurements with a reference cell or pyranometer would be the most straightforward and reliable approach. However, in our case, the datalogger that was intended to register insolation failed after 2 months. Since there is no nearby meteorological station, we had to look for other alternatives. Time series of satellite data are not yet readily available for locations in the tropics. NASA provides a tool where monthly average insolation can be obtained for every location in the world, based on 10 years of satellite monitoring ${ }^{8}$ (see Sections 'data acquisition' and 'Comparison with satellite data of monthly averages'). Such data can be very useful for designing solar systems. But for evaluating system performance, one prefers actual weather data instead of historic, climatic data.

As an alternative, we developed a new method to obtain estimated daily irradiation figures based on combining module current data of a number of nearby solar systems. The objective is to obtain reliable daily and monthly insolation figures that are representative for an area of a few square kilometres. Three key research questions are: is it possible to construct a time series of estimated irradiation figures based on module current data of nearby systems? How reliable are these estimates? Under what circumstances can this new method be applied?

This paper provides an answer to these questions. It describes a method to obtain time series of estimated daily irradiation in the absence of actual insolation measurements. A short introduction to this new method was recently published. ${ }^{9}$ Data acquisition is presented in Section 'data acquisition' and the various steps of the procedure are described in Section 'procedure for estimating daily irradiation figures'. In Section 'validation', our results with this method in Indonesia is validated against three other data sources, that is on-site measurements, a reference cell from another project and climate data from NASA satellites. Section 'discussion' discusses the outcomes. Section 'summary and conclusions' summarises the results and presents general conclusions.

\section{DATA ACQUISITION}

\section{Choice of datalogger}

Monitoring in remote areas requires reliable data loggers. To reduce possible influencing of the users, a small logger was chosen that can be integrated into the battery box of the SHS (see Figure 1a). This Sentry $\operatorname{logger}{ }^{10}$ has its own power source on which it can operate for about 5 years. Insolation data were obtained from a much more complicated datalogger from a World Bank project, that was installed in the same village (see Figure 1b). Failure of the external power source caused interruption of the insolation data acquisition after 2 months.

\section{Parameters measured with the data loggers}

Four parameters are measured at the input and output terminals of the battery charge regulator (BCR) of the SHS at 7-s intervals and stored as half-hourly averages. With shunt resistors, the PV-module current and the current to the load are measured. Battery voltage is taken at the battery terminals of the BCR. Voltage at the load terminal of the BCR is also measured. 


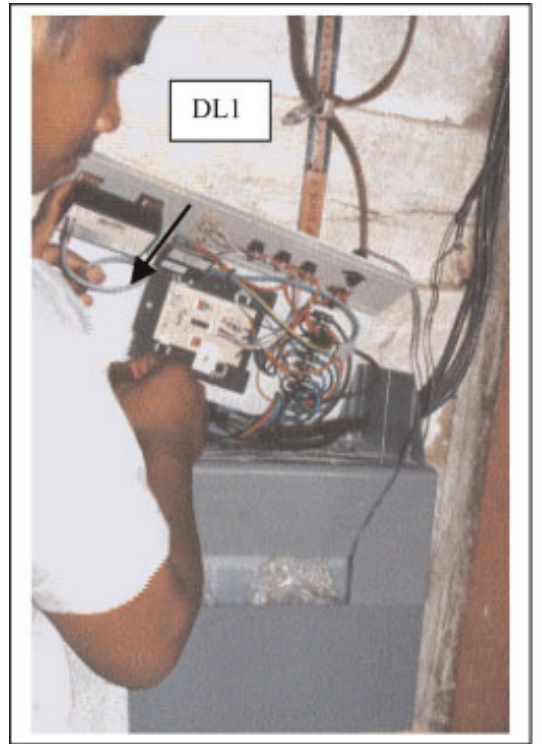

(a)

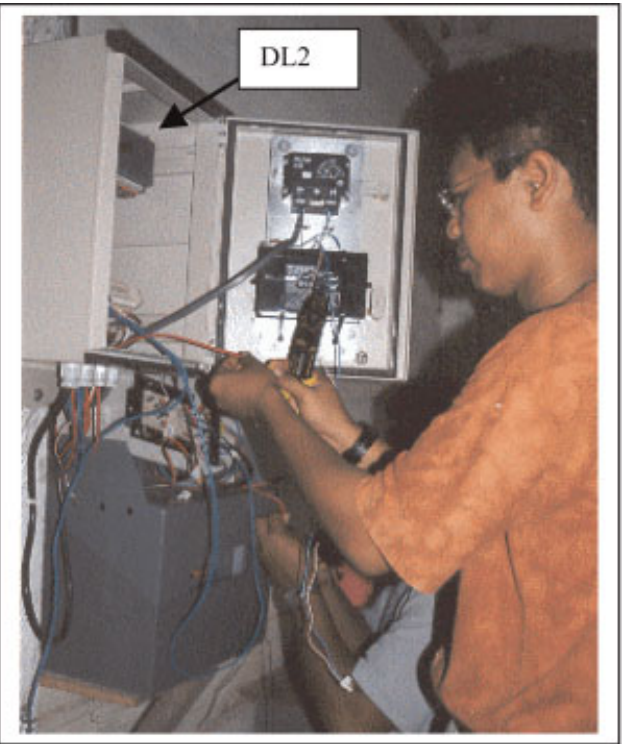

(b)

Figure 1. SHS battery box (grey box at bottom of (a) and (b)) with two different dataloggers in Kolaka, Indonesia. Figure 1a shows the small Sentry datalogger (marked DL1), which is integrated in the battery box. The rest of the electronics is the battery charge regulator. Figure $1 \mathrm{~b}$ shows the more complex logger from another project (marked DL2) from which we

expected to obtain insolation data

An important parameter in the analysis is the voltage of the PV-module. Laboratory measurements on the charge regulator (T12.10P of PT LEN, Indonesia) showed a constant voltage drop of $0.5 \mathrm{~V}$ between the module and battery connections, caused by a semiconductor in the charge regulator. PV-module voltage has been calculated by adding $0.5 \mathrm{~V}$ to the measured battery voltage, omitting the voltage drop over the cables, which is estimated to be around $0 \cdot 1-0 \cdot 2 \mathrm{~V}$ at maximum module current.

\section{$P V$-module temperature information}

Module temperature $T_{\mathrm{m}}$ is not one of the parameters that was measured continuously with the data loggers. Only in a 5-day period during an inspection visit in October 2003, horizontal irradiation measurements were made with a MacSolar insolation measurement device (from Solarc ${ }^{19}$ ). It uses a poly-crystalline cell, of which the cell temperature is also recorded. In these 5 days, the temperature range was in the order of $20-60^{\circ} \mathrm{C}$ (see Figure 2 ). Daily ambient temperature variations are typically in the range of $25-35^{\circ} \mathrm{C}$, depending on the time of the day. Results from a least squares fit were used in the rest of the analysis to obtain half-hourly module temperature estimates based on insolation, with an estimated error of about $3^{\circ} \mathrm{C}$.

\section{Insolation measurements}

Measuring insolation in solar systems is usually done with a reference cell that is attached in the same plane as the PV-array. Because only four data channels were available, we have chosen not to measure insolation at each SHS site. Instead, we expected to obtain insolation from a logger, attached to one of the solar homes systems in Polinggona as part of a World Bank project (see Figure 3 for a map of the monitoring area with the nine data loggers installed by BPPT-ECN and the World Bank logger). The World Bank logger uses a reference cell to measure insolation. Fraunhofer ISE in Freiburg, Germany, has built the data acquisition system for the World Bank project around a Gantner datalogger. Two months of reference cell measurements are used to validate the new method. 


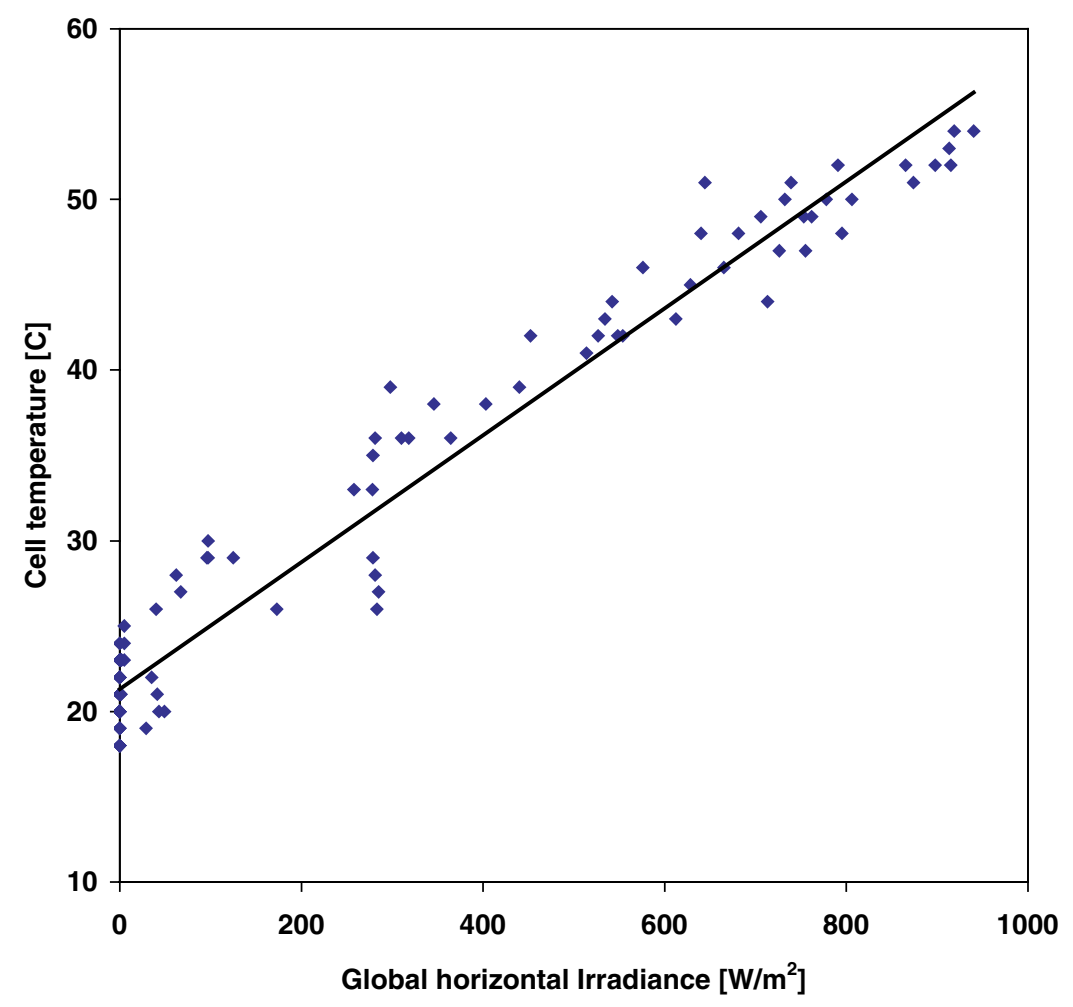

Figure 2. Relation between hourly averages of reference cell temperature and global horizontal irradiance in a 5-day measurement series in Pewisoa Jaya in October 2003. Measured with a MacSolar of (Solarc)

\section{Validation with 3 days of insolation measurements}

At one of the SHS locations, a MacSolar was installed for a few days in October 2003. It had been calibrated before at ECN by comparing it to a reference module that was calibrated by JRC Ispra. The resulting difference was within $\pm 1 \%$. For the field measurements, the MacSolar was placed horizontally on the roof of Toeng's new house in Pewisoa Jaya that has an un-obstructed horizon in all directions.

\section{Satellite data for validation purposes}

With the objective to support the design of solar systems for remote areas where measurement stations are limited, NASA developed the Surface meteorology and Solar Energy (SSE) database. Access is free via internet. The SSE data set is a continuous and consistent 10-year global climatology of insolation and meteorology data on a $1^{\circ}$ by $1^{\circ}$ grid system. Satellite data over the period 30th June 1983 to 1 st July 1993 have been used as input for the SSE database. Release 4 has been used for our analysis. Comparison by NASA with ground-based measurements showed an estimated uncertainty of $10-17 \%$ (RMS) and a bias error of $+3 \%{ }^{8}$

\section{PROCEDURE FOR ESTIMATING DAILY IRRADIATION FIGURES}

The procedure to construct a time series of daily irradiation figures uses only two measured parameters: battery voltage $V_{\mathrm{S}}$ and PV-module current $I_{\mathrm{A}}$. Half-hourly averages of PV-module currents are measured when the battery is being charged. Module currents and voltages are used in a one-diode model to determine the photocurrent, which is directly related to irradiance in the module plane. Deviations between calculated 


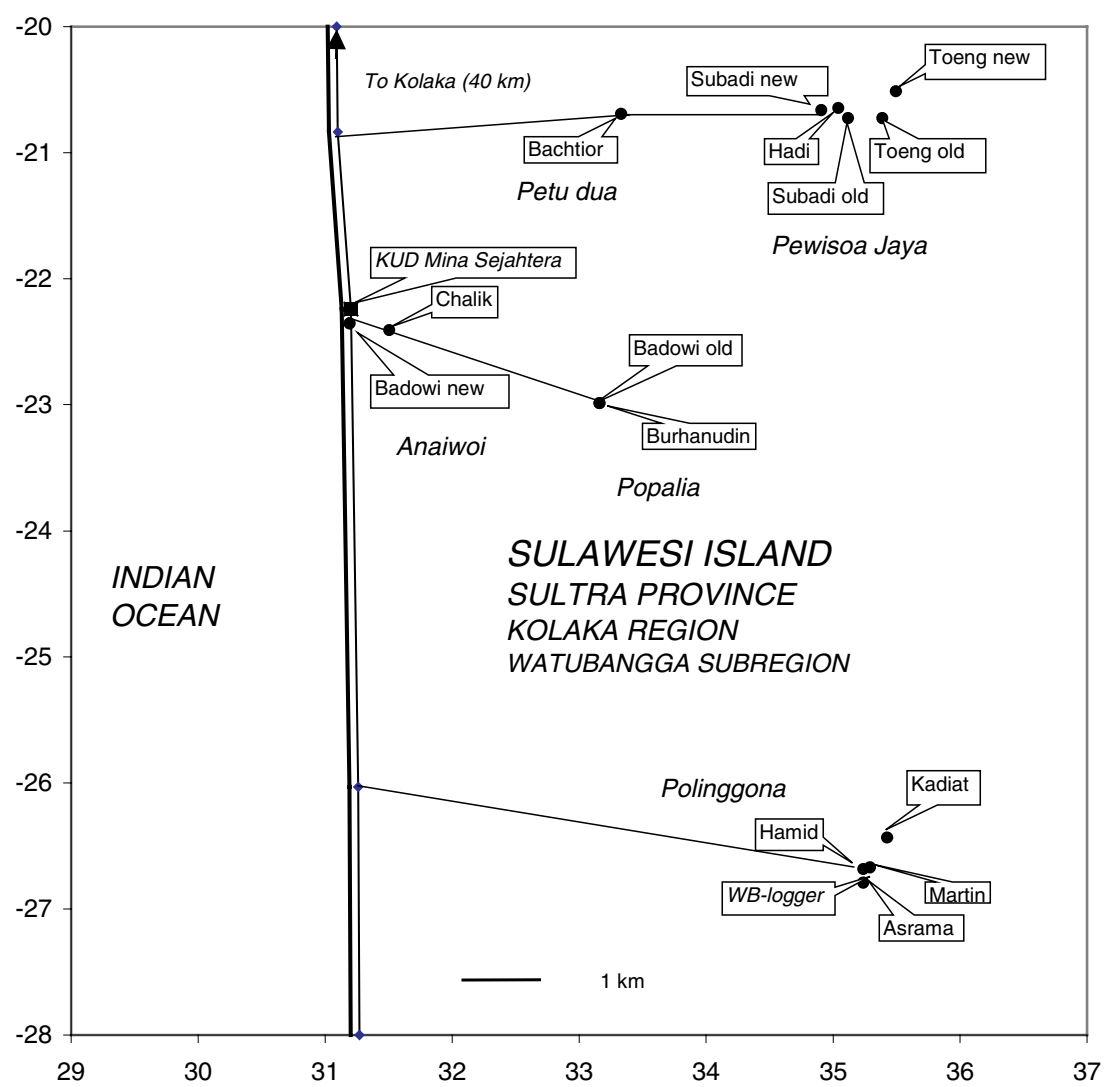

Figure 3. Map of Kolaka, Sulawesi, with the nine BPPT-ECN dataloggers and the World Bank logger. Horizontal: longitude in minutes $\left(+121^{\circ}\right.$ east), vertical: latitude in minutes $\left(-4^{\circ}\right.$ south). KUD Mina Sejahtera is the co-operative responsible for installation and maintenance of the SHSs

photocurrents and insolation occur when the battery is full and charging is cut off by the charge regulator, or when there is shading. To reduce these two effects, data of a number of different solar systems are combined. It is unlikely that full batteries or shading occurs with all the systems at the same time.

Four steps are required to calculate insolation from PV-module currents. These are described in Subsections 'calculating photocurrents based on PV-module currents' to 'combining time series of global horizontal irradiance of nearby systems':

(1) calculation of photocurrents from PV-module currents;

(2) scaling of photocurrents to obtain in-plane irradiance by equating maximum photocurrent in a year to maximum clear sky irradiance;

(3) conversion of in-plane irradiance to global horizontal irradiance;

(4) combining global horizontal irradiance data of different solar systems to calculate daily global horizontal irradiation that is representative for a larger area.

In Figure 4, a flow chart is presented of the first three steps to obtain a half-hourly average value of global horizontal irradiance for an individual solar system (steps 1-3).

\section{Calculating photocurrents based on PV-module currents}

The current-voltage (I-V) characteristic of a PV module can be described with a one-diode equation. Generally the short circuit current $I_{\mathrm{sc}}$ is related to the photocurrent $I_{\mathrm{L}}$, which is directly related to the in-plane irradiance $G_{\mathrm{I}}$ 


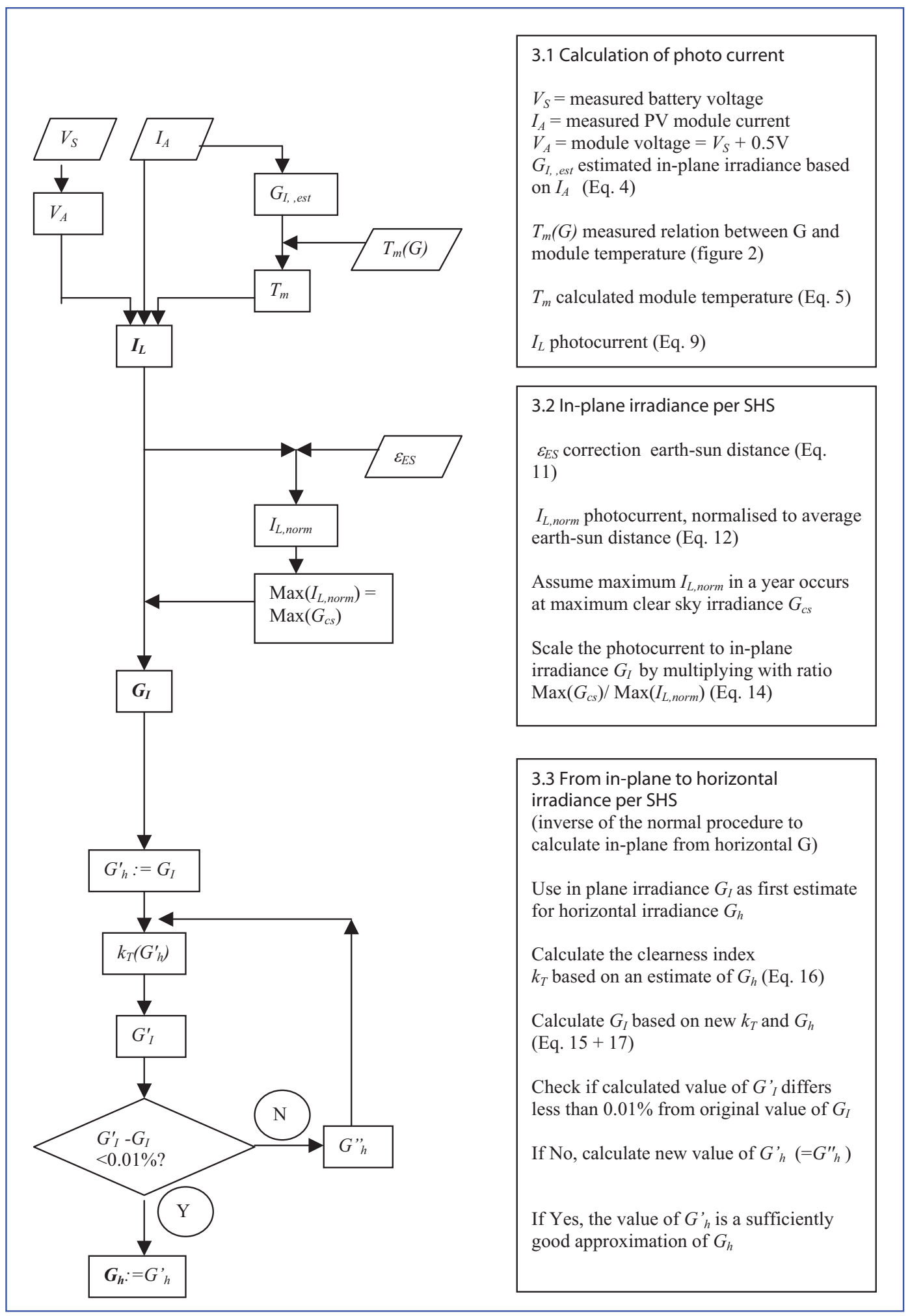

Figure 4. Flow chart for calculating one half-hourly value of global horizontal irradiance for a solar system based on measured battery voltage and module current of a non-horizontal PV module 
whenever spectral effects can be ignored and temperature is constant. It increases with increasing temperature since semiconductor band gaps generally decrease with temperature. In this section the photocurrent is estimated, based on the measured module current $I_{\mathrm{A}}$.

\section{I-V characteristic of a PV module}

The standard one-diode model of an illuminated PV-module consists of a current source, a diode and a shunt resistance $R_{\mathrm{sh}}$ in parallel and a resistance $R_{\mathrm{s}}$ in series. Module current $I$ and voltage $V$ are related as follows ${ }^{11}$ :

$$
I=I_{\mathrm{L}}-I_{0}\left(e^{\frac{V+I R_{\mathrm{S}}}{n V_{T}}}-1\right)-\frac{V+I R_{\mathrm{s}}}{R_{\mathrm{sh}}}
$$

$I_{0}$ is the diode reverse saturation current, which strongly depends on temperature and is typically in the order of microamperes. The fit parameter $n$ is known as the ideality- or diode quality factor, which varies between 2 at low currents and 1 at higher currents. ${ }^{12} V_{T}$ is defined as:

$$
V_{T}=\frac{k T_{\mathrm{m}} N_{\mathrm{s}}}{q}
$$

in which $q$ is the elementary charge $\left(1.602 \times 10^{-19} \mathrm{C}\right), k$ the Boltzmann constant $\left(1.381 \times 10^{-23} \mathrm{~J} / \mathrm{K}\right)$ and $N_{\mathrm{s}}$ is the number of cells in series. $V_{T}$ is linearly related to the module temperature $T_{\mathrm{m}}$.

\section{Temperature dependence of $I-V$-curve parameters}

To determine module temperature based on the relation with irradiance as shown in Figure 2, estimated insolation is sufficient. Insolation is assumed to be linearly related to the module current, with a scaling factor that is determined by equating the maximum module current in a year to the maximum clear sky irradiance $\left(G_{\mathrm{cs}}\right)$ in a year. This results in the following relation for a first estimate of in-plane irradiance $G_{\mathrm{I} \text {, est }}\left(\mathrm{W} / \mathrm{m}^{2}\right)$ that is only used for calculating module temperatures:

$$
G_{\mathrm{I}, \mathrm{est}}=\frac{\text { annual } \max \left(G_{\mathrm{cs}}\right)}{\text { annual } \max \left(I_{\mathrm{A}}\right)} I_{\mathrm{A}}
$$

This estimated irradiance is used with the empirical relation between cell temperature and insolation of Figure 2 to obtain calculated PV-module temperatures for the whole 2.5-year measurement period. In the rest of the analysis, the following empirical relation is used for the module temperature (in Kelvin):

$$
T_{\mathrm{m}}=294 \cdot 4+0 \cdot 03717 G_{\mathrm{I}, \mathrm{est}}
$$

For irradiance estimates based on measured module currents, it is crucial to explicitly include temperature effects of the module. According to Townsend, ${ }^{13}$ the parameters of many PV modules obey the following temperature dependence in relation to a reference temperature $T_{\mathrm{m}}$, ref (e.g. at the STC temperature of $298 \mathrm{~K}$ ):

$$
\begin{gathered}
V_{T}=V_{T, \text { ref }}\left(\frac{T_{\mathrm{m}}}{T_{\mathrm{m}, \text { ref }}}\right) \\
I_{0}=I_{0, \text { ref }}\left(\frac{T_{\mathrm{m}}}{T_{\mathrm{m}, \text { ref }}}\right)^{3} \exp \left[\frac{E_{\mathrm{g}} N_{\mathrm{s}}}{n V_{T, \text { ref }}}\left(1-\frac{T_{\mathrm{m}, \text { ref }}}{T_{\mathrm{m}}}\right)\right]
\end{gathered}
$$

with $E_{\mathrm{g}}$ the band-gap energy of $1 \cdot 12 \mathrm{eV}$ for silicon and $N_{\mathrm{s}}$ the number of cells in series (36 for the MSX53).

When the conditions for an open circuited module are entered in Equation (1) and solving for $I_{0}$, while using Equations (7) and (3), the reverse saturation current at the reference temperature, $I_{0, \text { ref }}$ can be determined:

$$
I_{0, \text { ref }}=\left[\left(1+\frac{R_{\mathrm{s}}}{R_{\mathrm{sh}}}\right) I_{\mathrm{sc}}-\frac{V_{\mathrm{oc}}}{R_{\mathrm{sh}}}\right] \exp \left(-\frac{V_{\mathrm{oc}}}{n V_{T, \mathrm{ref}}}\right)
$$


Table I. Module parameters used in the I-V-curve modelling

\begin{tabular}{lcc}
\hline & Manufacturer's data sheet & Assumed \\
\cline { 2 - 3 } & BP-Solarex MSX-53 & $1 \cdot 3$ \\
\hline Short circuit current $I_{\mathrm{sc}}$ & $3 \cdot 4 \mathrm{~A}$ & $1 \cdot 2 \mathrm{~V}$ \\
Open-circuit voltage $V_{\mathrm{oc}}$ & $20 \cdot 6 \mathrm{~V}$ & $0 \cdot 48 \Omega$ \\
Diode quality factor $n$ & & $200 \Omega$ \\
$n V_{T, \text { ref }}=n k_{T} N_{\mathrm{s}} / q$ & & $1 \cdot 12 \mathrm{eV}$ \\
Series resistance $R_{\mathrm{s}}$ & 36 & \\
Shunt resistance $R_{\mathrm{sh}}$ & 36 \\
Band gap silicon $E_{\mathrm{g}}$ & & \\
Number of cells in series & & \\
\hline
\end{tabular}

With the module parameters of Table I, $I_{0 \text {,ref }}$ amounts to $0 \cdot 116 \mu \mathrm{A}$. With cell temperatures in the range of $20-60^{\circ} \mathrm{C}$, the reverse saturation current $I_{0}$ varies between 0.062 and $5.53 \mu \mathrm{A}$.

\section{Calculation of the photo current}

Based on half-hourly averages of module current $I_{\mathrm{A}}$ and voltage $V_{\mathrm{A}}$, the light current $I_{\mathrm{L}}$ can be calculated by using Equation (1):

$$
I_{\mathrm{L}}=I_{\mathrm{A}}+I_{0}\left(e^{\frac{V_{\mathrm{A}}+I_{\mathrm{A}} R_{\mathrm{s}}}{n V_{T}}}-1\right)+\frac{V_{\mathrm{A}}+I_{\mathrm{A}} R_{\mathrm{s}}}{R_{\mathrm{sh}}}
$$

\section{Assumptions on PV-module parameters for modelling of the $I-V$ curve}

Field measurements of the module parameters were not accurate enough to be useful. Therefore, we assume typical values for $V_{T}, R_{\mathrm{s}}$ and $R_{\mathrm{sh}}$ and use the manufacturer's data sheet for values of $V_{\mathrm{oc}}$ and $I_{\mathrm{sc}}$. The simulation tool PVSYST of the University of Geneva ${ }^{18}$ recommends using a constant diode quality factor $n=1 \cdot 3$ for polycrystalline modules, resulting in a value for $n V_{T, \text { ref }}$ of $1.2 \mathrm{~V}$ for 36-cell modules. PVSYST also recommends using a default module shunt resistance $R_{\mathrm{sh}}$ of $200 \Omega$. Most poly-crystalline modules with $10 \times 10 \mathrm{~cm}^{2}$ cell tested at ECN have a series resistance in the order of $10 \mathrm{~m} \Omega$ per cell. Ten metres of $2.5 \mathrm{~mm}^{2}$ cable to connect the module to the charge regulator, results in an additional resistance of $70 \mathrm{~m} \Omega$. To account for contact resistance and some module degradation, another $50 \mathrm{~m} \Omega$ is assumed, resulting in a total series resistance of $0.48 \Omega$. In Table I the module parameters are presented that have been used in the I-V-curve modelling.

An example of calculated photocurrents using module parameter values of Table I and measured values of battery voltages $V_{\mathrm{s}}$ and module currents $I_{\mathrm{A}}$ is shown in Figure 5. For the module currents at the high insolation end, the photocurrent is about $20 \%$ higher than the measured module current. This difference is mainly determined by the diode term in Equation (9). The offset from a straight line has a value of about $15 \mathrm{~V} /$ $200 \Omega=75 \mathrm{~mA}$ and is caused by the right hand term in Equation (9).

All systems show similar graphs as shown in Figure 5. It can be concluded that the assumption that irradiance is proportional to the module currents (the straight line in Figure 5, equivalent to $I_{\mathrm{L}}=I_{\mathrm{A}}$ in Eq. 9) is a first estimate that leads to errors up to about $20 \%$. Note that Figure 5 is not a comparison between theory and measurements. This is provided later, in Figure 10.

\section{Time series of in-plane irradiance per solar home system}

In this section, the steps are described to convert photocurrents into in-plane irradiance. With a clear sky model, the maximum clear sky irradiance is related to the highest values of the photocurrent in a year. To be able to select a maximum value in a frequency distribution of photocurrents, a small correction has to be applied to take 


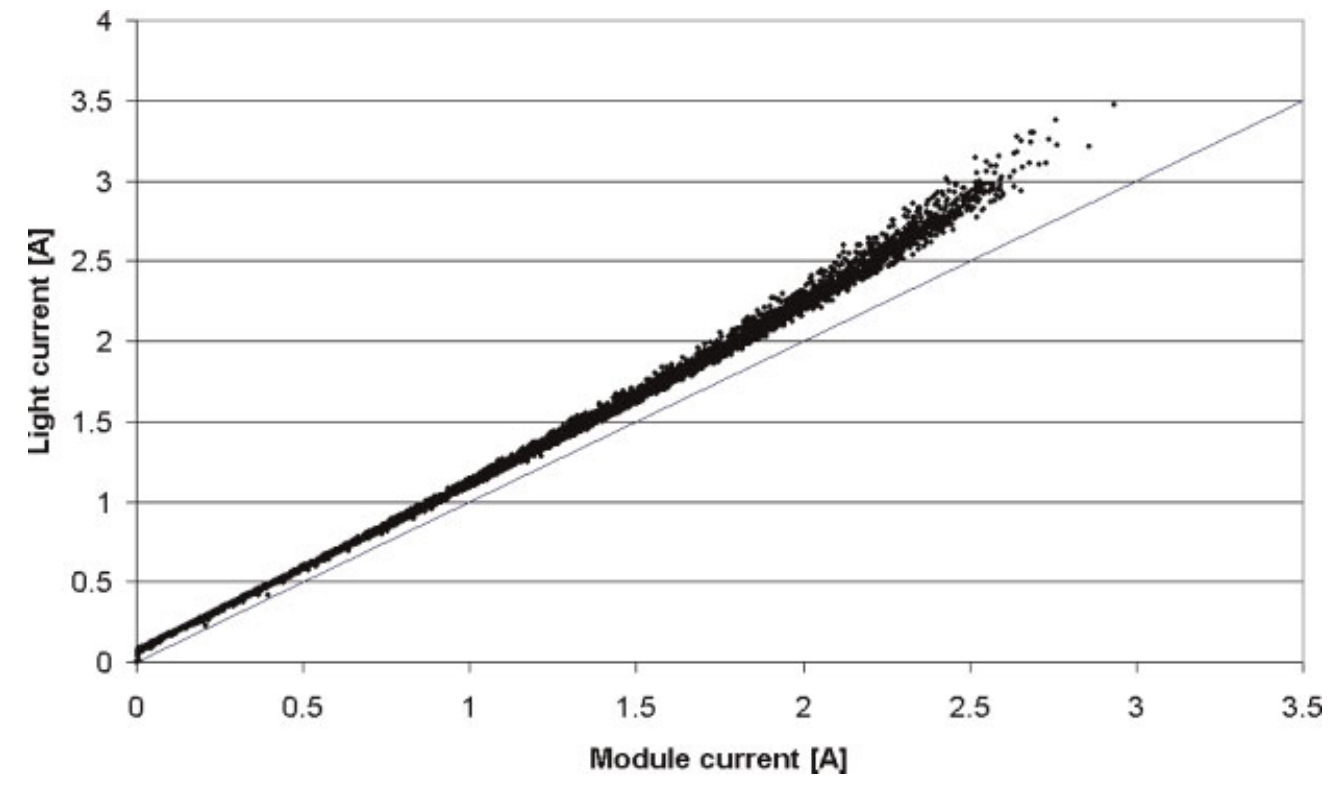

Figure 5. Calculated light current versus measured module current of Toeng's SHS in 2002, showing that the light current is $20 \%$ higher than the module current at the high insolation end

into account variations in the distance from the earth to the sun. It is only a small correction, but easy to apply and helpful in reducing the spread in the distribution of the photocurrents (see Figure 6).

Compensation for seasonal variations in the earth-sun distance

Differences of the earth-sun distance of about $1.7 \%$ over the year, result in a variation of the extraterrestrial solar flux $G_{0 \mathrm{~m}}$ in a plane normal to the radiation of about $3 \%$, with $G_{\mathrm{sc}}$ the solar constant of $1367 \mathrm{~W} / \mathrm{m}^{2}{ }^{11}$ :

$$
G_{0 \mathrm{~m}}=G_{\mathrm{sc}} \varepsilon_{\mathrm{ES}}
$$

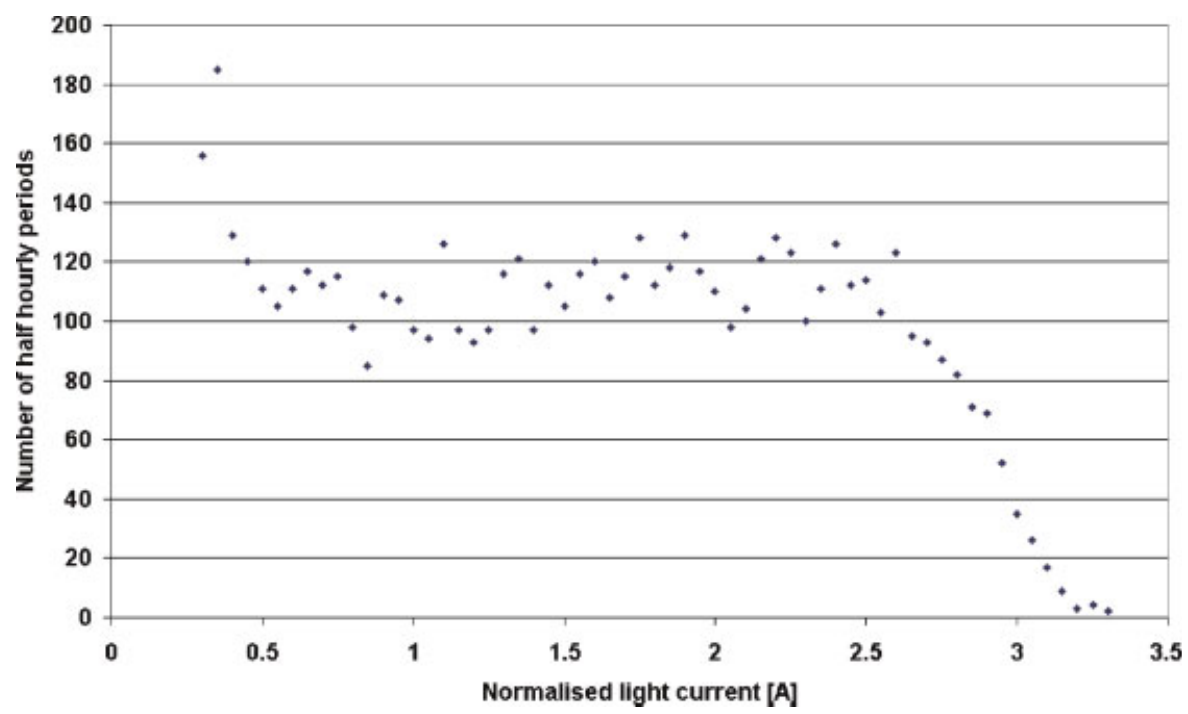

Figure 6. Frequency distribution of the photocurrent $I_{\text {Lnorm }}$, normalised to the average earth-sun distance of Burhanudin's SHS in 2002 
where $\varepsilon_{\mathrm{ES}}$ is the correction for the earth-sun distance on day $m$ of the year:

$$
\varepsilon_{\mathrm{ES}}=1+0 \cdot 033 \cos \left(\frac{360 m}{365}\right)
$$

The time series of light current $I_{\mathrm{L}}$ can now be normalised to the average distance according to:

$$
I_{\text {Lnorm }}=\varepsilon_{\mathrm{ES}}^{-1} I_{\mathrm{L}}
$$

\section{Maximum light current throughout the year}

A typical frequency distribution function of normalised light currents of a PV module in Kolaka is shown in Figure 6. A photocurrent of 3.2 A corresponds to the maximum clear sky irradiance. With reflection of direct light on clouds, irradiance can reach $1300 \mathrm{~W} / \mathrm{m}^{2}$ for short periods of time (seconds to minutes). Usually, half-hourly averages are below $1000 \mathrm{~W} / \mathrm{m}^{2}$. However, in a small number of half-hourly periods high irradiance can persist, which then results in a higher irradiance figure than the clear sky maximum.

Global clear sky irradiance

On a clear day, the global horizontal clear sky irradiance $G_{\mathrm{cs}}$ can be modelled as follows ${ }^{14}$

$$
G_{\mathrm{cs}}=\alpha G_{\mathrm{sc}} \varepsilon_{\mathrm{ES}}\left(\cos \theta_{z}\right)^{1.15}
$$

where $\alpha$ depends on the turbidity of the atmosphere. According to a model of Bourges ${ }^{15} \alpha=0 \cdot 70$, while according to a model of Perrin de Brichambaut and Vauge ${ }^{16} \alpha=0 \cdot 81$. Two measurements of global horizontal irradiance at different times on the same clear day in the rainy season in Kolaka resulted in an average value of $\alpha=0.765$. It implies a maximum clear sky irradiance, when the sun is in zenith, of $1045 \mathrm{~W} / \mathrm{m}^{2}$.

\section{Scaling of light currents to in-plane irradiance}

Due to the small tilt angles of the PV-modules in Kolaka, part of the year, the sun will be exactly perpendicular to each module. It is very likely that a few times a year the sun is more or less perpendicular to the PV module when the sky is clear. Therefore, it can be safely assumed that the maximum value of the light current in a year takes place at the time of maximum clear sky irradiance in the module plane. This provides the means to gauge the photocurrent time series and to convert them into in-plane irradiance values:

$$
G_{\mathrm{I}}=\frac{\text { annual } \max \left(G_{\mathrm{cs}}\right)}{\text { annual } \max \left(I_{\mathrm{L}, \mathrm{norm}}\right)} I_{\mathrm{L}}
$$

\section{From in-plane to horizontal global insolation}

To make time series from different solar systems comparable, the next step is to transform each series from in-plane to global horizontal insolation. The isotropic diffuse model of Liu and Jordan relates insolation on a tilted plane to horizontal insolation. ${ }^{11}$ When the PV-module tilt angle $\beta$ is small, ground reflection can be ignored, which results in the following relation between $G_{\mathrm{I}}$ and the beam component $\left(G_{\mathrm{b}}\right)$ and diffuse component $G_{\mathrm{d}}$ of $G$ (with $R_{\mathrm{b}}$ a geometrical factor depending on the position of the sun in relation to the module):

$$
G_{\mathrm{I}}=G_{\mathrm{b}} R_{\mathrm{b}}+G_{\mathrm{d}}\left(\frac{1+\cos (\beta)}{2}\right)
$$


The hourly clearness index $k_{T}$ is defined as the ratio between the hourly horizontal insolation at the earth surface and hourly horizontal insolation at the top of the atmosphere:

$$
k_{T}=\frac{G_{\mathrm{h}}}{G_{0}}
$$

For the diffuse component $G_{\mathrm{d}}$, the empirical model of Erbs et al. ${ }^{17}$ was used, which states the following relations for the ratio between hourly diffuse and total insolation as a function of the hourly clearness index:

$$
\begin{gathered}
\frac{G_{d}}{G}=1 \cdot 0-0 \cdot 09 k_{T} \quad \text { for } k_{T} \leq 0 \cdot 22 \\
\frac{G_{\mathrm{d}}}{G}=0 \cdot 9511-0 \cdot 1604 k_{T}+4 \cdot 388 k_{T}^{2}-16 \cdot 638 k_{T}^{3}+12 \cdot 336 k_{T}^{4} \quad \text { for } 0 \cdot 22 \leq k_{T} \leq 0 \cdot 80 \\
\frac{G_{\mathrm{d}}}{G}=0 \cdot 165 \quad \text { for } k_{T} \geq 0 \cdot 80
\end{gathered}
$$

Since we start with insolation figures in a tilted plane and want to calculate the horizontal component, the value of $k_{T}$ is not directly known. In an iterative procedure, in-plane irradiance $G_{\mathrm{I}}$ is used as a starting value for the horizontal insolation $G_{\mathrm{h}}$ for the calculation of $k_{T}$. This iterative procedure is stopped when the difference between the calculated $G_{\mathrm{I}}^{\prime}$ and the originally measured $G_{\mathrm{I}}$ is less than $0.01 \%$. Usually this occurs within 10 iteration steps.

\section{Combining time series of global horizontal irradiance of nearby systems}

The objective of our procedure is to obtain reliable daily and monthly insolation figures that are representative for an area of one or more villages. Each individual time series of module currents is unreliable, because part of the time one can expect shading or a full battery. For a single system, this will result in an underestimate of the insolation during these periods of the day. By comparing half-hourly data from different systems and discarding the data from systems that are substantially lower than the others, one can reduce the chance of underestimation of the daily insolation of the area. An example of the effect of shading is shown in Figure 7.

\section{Exclusion of outliers}

In combining the values from different systems, there is an asymmetry in the direction of expected outliers. In none of the time series there have been any indication of measured module currents that are higher than the value that could have been expected for that time of the day. On the other hand, all time series show now and then lower values than expected, see, for example Figure 8. A procedure for discarding outliers only has to focus on outliers in the down side direction.

Differences are expected in the starting times of the half hour periods of the different data loggers, resulting in a maximum error of $\pm 0 \cdot 25 \mathrm{~h}$ in overlaying the time series of different systems. Maximum effect of half an hour shift in the clear sky radiation (Eq. 13) is a difference of about $125 \mathrm{~W} / \mathrm{m}^{2}$. With some extra margin for measurement errors, a difference of $150 \mathrm{~W} / \mathrm{m}^{2}$ with the maximum value within that half an hour is used as the maximum difference before a measurement is classified as an outlier. Half-hourly irradiance values that are representative for the area are calculated by taking the average of those values that differ less than $150 \mathrm{~W} / \mathrm{m}^{2}$ from the maximum. An example of how this procedure works out for four systems in the village of Polinggona is shown in Figure 8. Two of the four systems do not contribute to the average value for Polinggona between 10.00 and 16.00 , because they differ more than $150 \mathrm{~W} / \mathrm{m}^{2}$ from the maximum. From 12.30 to 13.30 the Polinggona average is based on one system only.

\section{Results of the outlier removal procedure}

The four systems in Polinggona show the longest uninterrupted series of data. With the help of this procedure, a 2.5-year time series of daily irradiation in Kolaka has been calculated that can be compared to other sources. The calculated insolation for 2002 is shown in Figure 9. 


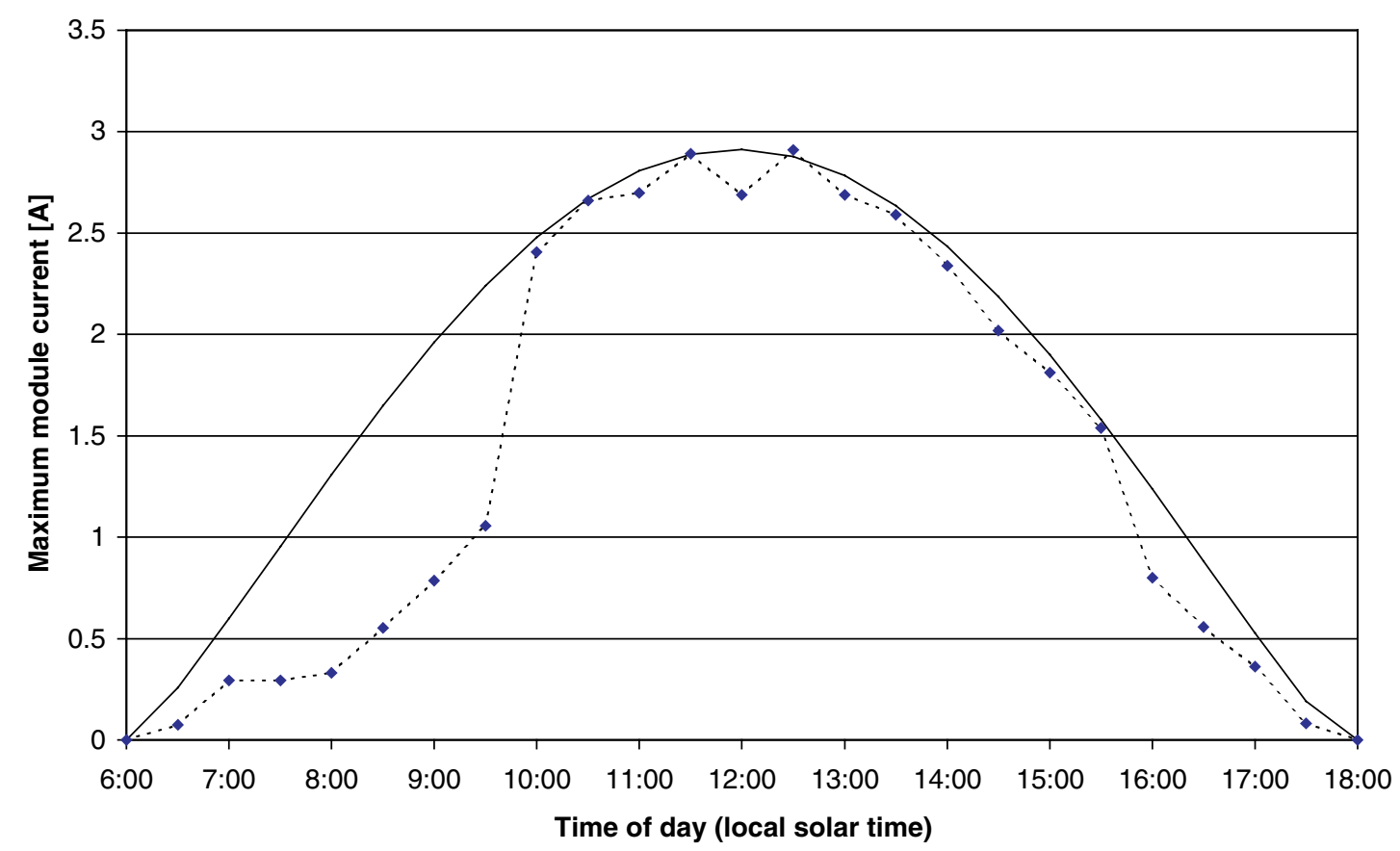

Figure 7. Measured monthly maximum module current of SHS of Hamid in Polinggona (dots) and calculated clear sky irradiance, during May 2001. Before 10 A.M. there is substantial shading

\section{Error estimates}

A number of systematic errors affect the annual average of calculated irradiation figures:

(a) Shading will decrease irradiance in the beginning and end of the day. The resulting systematic error in calculated daily irradiation is estimated to be around -2 to $-3 \%$.

(b) To compensate for possible shading or a full battery at individual systems, only those insolation measurements are included that differ less than $150 \mathrm{~W} / \mathrm{m}^{2}$ from the maximum value. The lower this value, the higher the calculated daily irradiation figures.

(c) Maximum clear sky irradiance was calculated to be $1045 \mathrm{~W} / \mathrm{m}^{2}$ based on two measurements. The estimated error is $\pm 5 \%$.

(d) The maximum light current during a year (based on Figure 7) has an estimated error of about $\pm 0 \cdot 15 \mathrm{~A}$, which is equal to about $\pm 5 \%$.

(e) Maximum expected difference in starting times of the loggers is $30 \mathrm{~min}$. This results in an overestimation of the annual average by about $+3 \%$.

(f) Weather differences within the area will also lead to an overestimate of the annual average. In a flat area, with similar distances to the seashore, errors due to weather effects are estimated to be in the order of $+1 \%$ when systems are within a radius of $1 \mathrm{~km}$, as is the case for Polinggona. It is estimated to be in the order of $+5 \%$ when systems are included at distances of $10 \mathrm{~km}$.

(g) Furthermore, there is still a small chance that all included systems experience a full battery or shading at the same time, resulting in an underestimate of actual insolation.

Combining the systematic errors from the above sources, the total systematic error in the annual average irradiation is estimate to be in the range from 10 to $15 \%$. When it is possible to check the calculated figures against direct measurements over a limited period of time (a few weeks to a few months), the systematic error is in the same range as that of the reference cell: $5-10 \%$. 


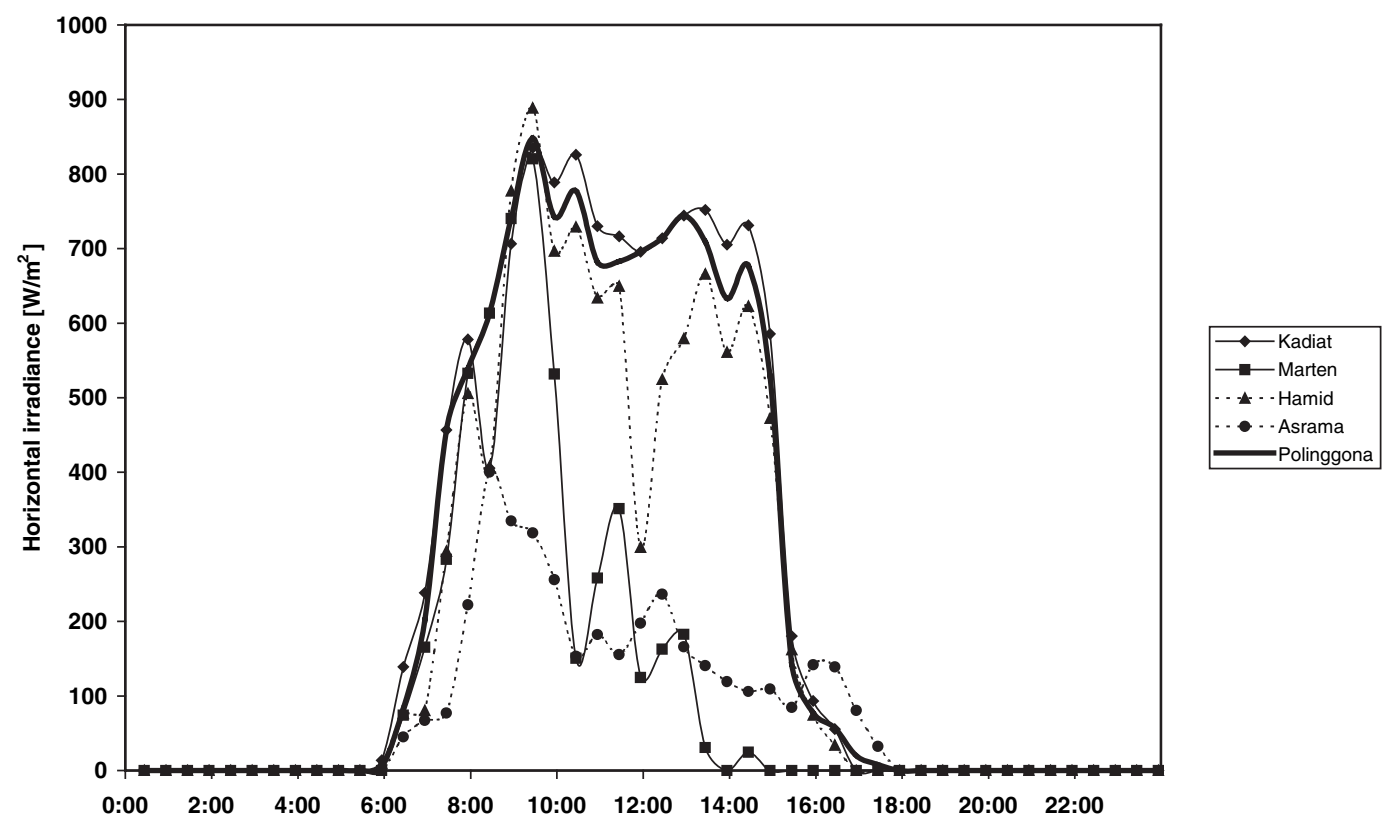

Figure 8. Calculated global horizontal irradiance of four individual systems (Kadiat, Marten, Hamid, Asrama) in Polinggona village and their combined value (Polinggona) on 10 October 2003

\section{VALIDATION}

Three different data sets have been used to validate the proposed method. They are all three less than ideal for the purpose of direct comparison. Three days of horizontal insolation measurements have the disadvantage that they were obtained at a distance of $11 \mathrm{~km}$ from Polinggona, where the four loggers are located on which the

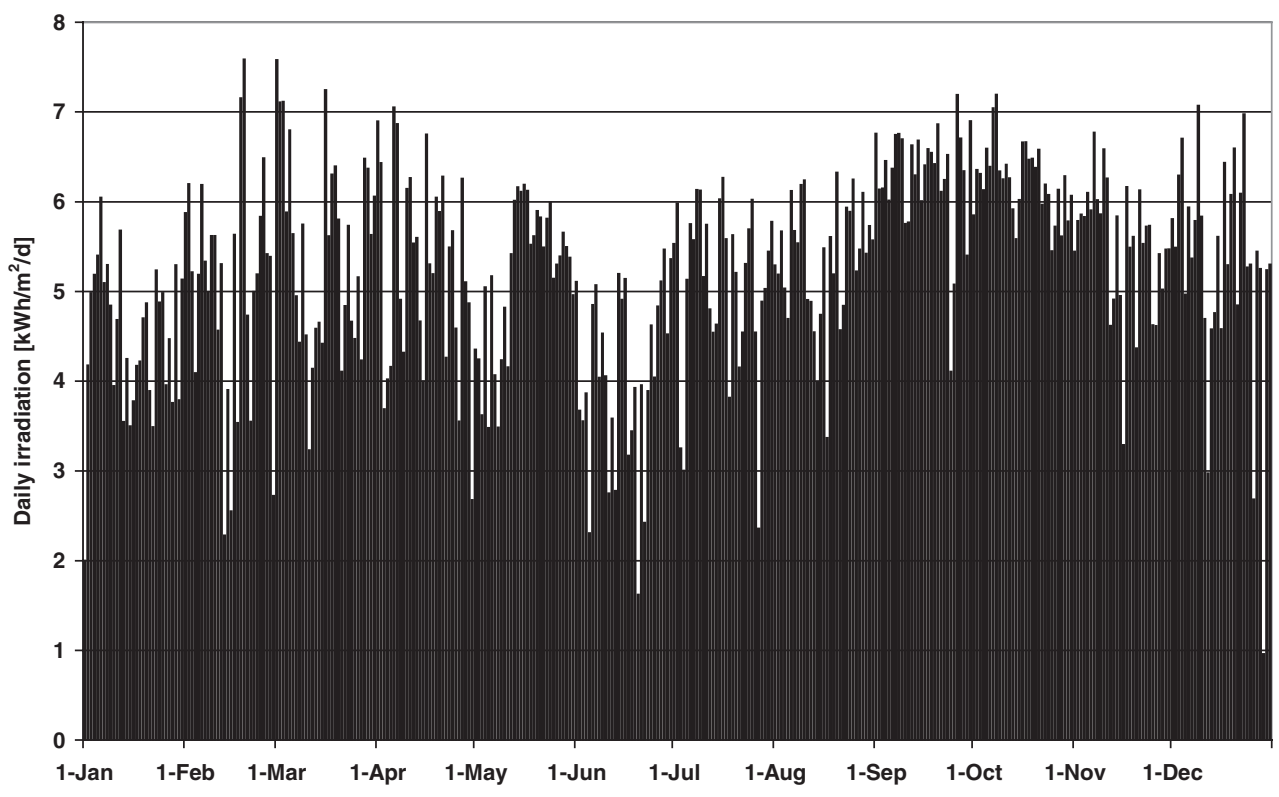

Figure 9. Calculated daily irradiation in 2002 in Polinggona in $\mathrm{kWh} / \mathrm{m}^{2} / \mathrm{d}$ 
Table II. Comparison of measured values of global horizontal insolation in Pewisoa Jaya with calculated insolation based on four solar home systems in Polinggona at $11 \mathrm{~km}$ distance

\begin{tabular}{lccc}
\hline Day in 2003 & $\begin{array}{c}\text { Calculated } \\
{\left[\mathrm{kWh} / \mathrm{m}^{2} / \mathrm{d}\right]}\end{array}$ & $\begin{array}{c}\text { Measured }(\mathrm{MacSolar}) \\
{\left[\mathrm{kWh} / \mathrm{m}^{2} / \mathrm{d}\right]}\end{array}$ & $\begin{array}{c}\text { Difference } \\
{[\%]}\end{array}$ \\
\hline 10th October & $5 \cdot 69$ & $5 \cdot 59$ & $+1 \cdot 8$ \\
11th October & $6 \cdot 15$ & 6.63 & $-7 \cdot 3$ \\
12th October & 4.48 & 4.92 & $-9 \cdot 0$ \\
Average & $5 \cdot 44$ & $5 \cdot 71$ & $-4 \cdot 8$ \\
\hline
\end{tabular}

calculated insolation was based. Another series of 2 months of reference cell measurements was made at the right location: the centre of Polinggona village. But these measurements were made in a $10^{\circ}$ tilted plane, requiring transformation to a horizontal plane first before a comparison can be made. Monthly averages of insolation based on historical climate data from satellites allow for identification of large systematic errors. But calculated monthly insolation averages can be outside 10-year climate extremes due to extreme weather conditions. However, all three combined, results in a sufficient level of validation of the proposed method.

\section{Comparison with on site insolation measurements}

In October 2003, horizontal insolation was measured continuously over a 5-day period with a MacSolar at the new house of Toeng in Pewisoa Jaya. Table II shows for the 3 full days in the 5-day measurement period that the

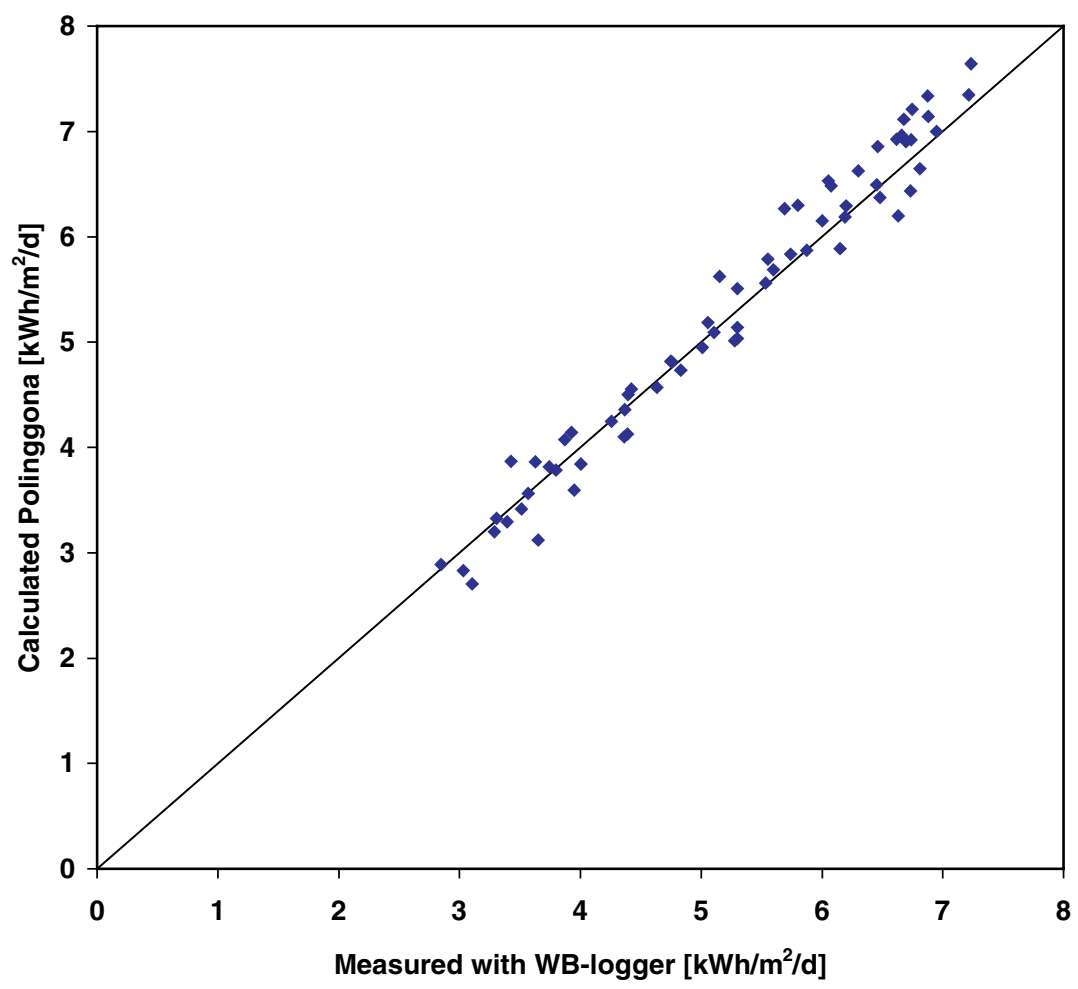

Figure 10. Comparison of calculated daily irradiation figures based on the four dataloggers in Polinggona with World Bank datalogger measurements in Polinggona over the period of 17th September to 22nd November 2001 
calculated values are on average about $5 \%$ below the measured daily irradiation values. Part of the differences can be attributed to the distance of $11 \mathrm{~km}$ between the measurement site and Polinggona. To eliminate this distance effect, in the following section, another set of measurements were used, coming from Polinggona.

\section{Comparison with reference cell in Polinggona}

Two months of insolation measurements with a reference cell from a World Bank project data logger were used to validate the calculated insolation figures. With the same procedure as described in Section 'from in-plane to horizontal global insolation', the measured insolation in the tilted plane of the World Bank logger was converted to horizontal insolation. First, the four systems in Polinggona were used to calculate daily global horizontal insolation. A comparison of calculated and measured values over a 2-month period in 2001 is presented in Figure 10. On average, the calculated values for Polinggona are only $0.07 \mathrm{kWh} / \mathrm{m}^{2} / \mathrm{d}(1.3 \%)$ higher than the measured values. The standard error amounts to $0.24 \mathrm{kWh} / \mathrm{m}^{2} / \mathrm{d}(5 \%)$, the RMSE $=0 \cdot 26 \mathrm{kWh} / \mathrm{m}^{2} / \mathrm{d}(5 \%)$ and $R^{2}$ amounts to 0.971 . Three of the four loggers in Polinggona are only 100-200 m from the World-Bank logger and the fourth about $600 \mathrm{~m}$. It can be concluded that there is a very good correlation between measured and calculated values when the loggers are not too far apart (within about $1 \mathrm{~km}$ ).

Data from eight loggers in Polinggona, Pewisoa Jaya and Popalia were combined to calculate a time series of insolation that is supposed to be representative for the Kolaka region, an area of about 10 by $10 \mathrm{~km}$. Figure 11 shows that the comparison with the measured data is not very well: the calculated values are on average $0.58 \mathrm{kWh} / \mathrm{m}^{2} / \mathrm{d}(11 \%)$ higher than the measured values $\left(R^{2}=0.942\right)$. The standard error is $0.31 \mathrm{kWh} / \mathrm{m}^{2} / \mathrm{d}(6 \%)$ and the RMSE $0.66 \mathrm{kWh} / \mathrm{m}^{2} / \mathrm{d}(13 \%)$. On top of the weather differences between the four villages, there is another effect that influences the calculated values. The more time series are included to calculate the insolation, the higher the average calculated value of the insolation becomes. The reason is that for calculation of the half-hourly insolation value, only those registrations are included, which differ less than $150 \mathrm{~W} / \mathrm{m}^{2}$ with the

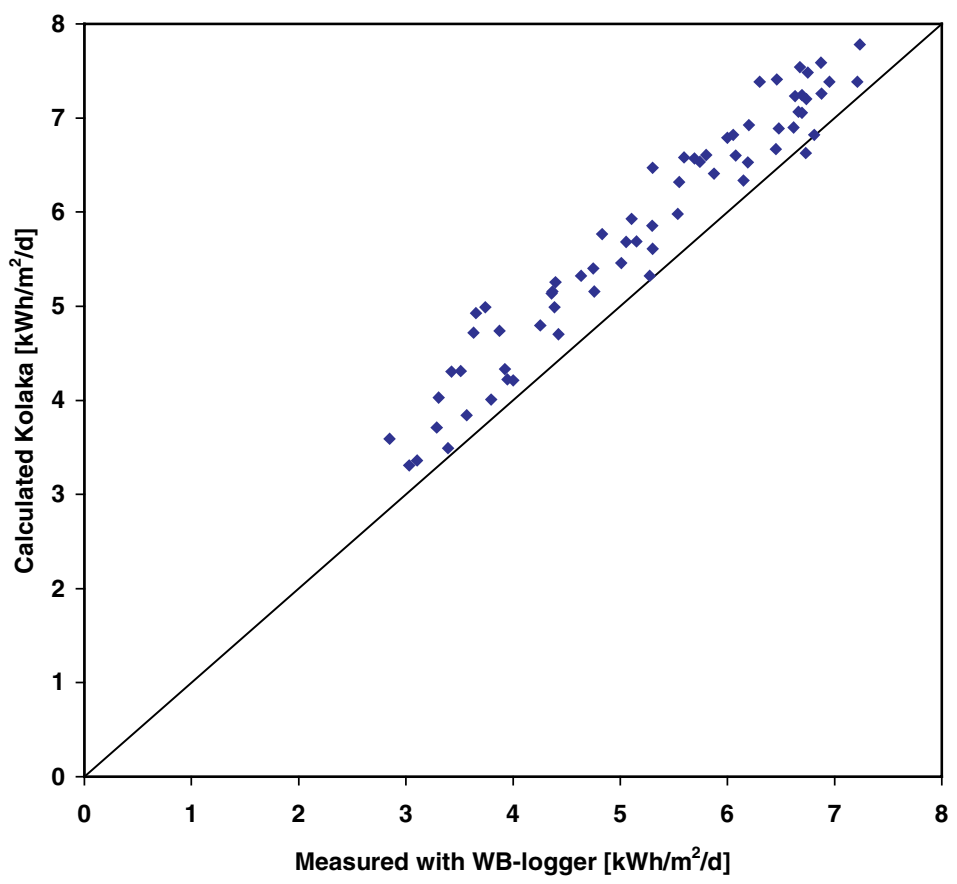

Figure 11. Calculated daily irradiation figures for Kolaka based on all eight data loggers compared with World Bank data logger measurements in Polinggona over the period of 17th September to 22nd November 2001 
maximum of all loggers for that half-hour period. Adding data from an additional logger results in maximum values of half-hourly insolation that are either the same or higher.

\section{Comparison with satellite data of monthly averages}

There is no meteorological station near Kolaka that could provide a basis for comparison. Satellite cloud cover and radiation data over a 10-year period are the basis for the NASA SSE data base. ${ }^{8}$ The SSE data set represents the average climate in a $1^{\circ}$ by $1^{\circ}$ grid pattern. Average monthly irradiation figures are compared in Figure 12. Annual average insolation of the satellite data is $4 \%$ higher than the average calculated using PV-module currents. When the monthly values in the Polinggona data are averaged over 2 or 3 years and compared on a monthly basis with the satellite data, the mean bias error is $-3.9 \%$, with a standard deviation of $6.4 \%$ and a maximum difference of $-15.9 \%$. Only in 3 of the 32 months, the SHS data were more than $0 \cdot 1 \mathrm{kWh} / \mathrm{m}^{2} / \mathrm{d}$ below the 10 -year minima of the satellite data. Taking into account the NASA-reported $+3 \%$ bias of the satellite data, it can be concluded that there is an excellent agreement between these two data sets.

\section{DISCUSSION}

We have shown here that it is possible to calculate a time series of daily irradiation figures based on measured PV-module currents, that closely matches measured values of daily and monthly insolation. However, there are a number of remaining uncertainties. If distances are around $1 \mathrm{~km}$, weather differences need not be regarded. But at $10 \mathrm{~km}$ distance, differences in weather at the different locations, results in an overestimation of insolation, especially on cloudy days. A more accurate determination of the distance over which weather differences can be omitted needs further investigation, which was not possible in the framework of our current monitoring work in Indonesia.

Validation of the methodology was only limited to a single area. Close to the equator, where PV-modules are placed almost horizontally, the required transformation from tilted to horizontal irradiance does not involve a

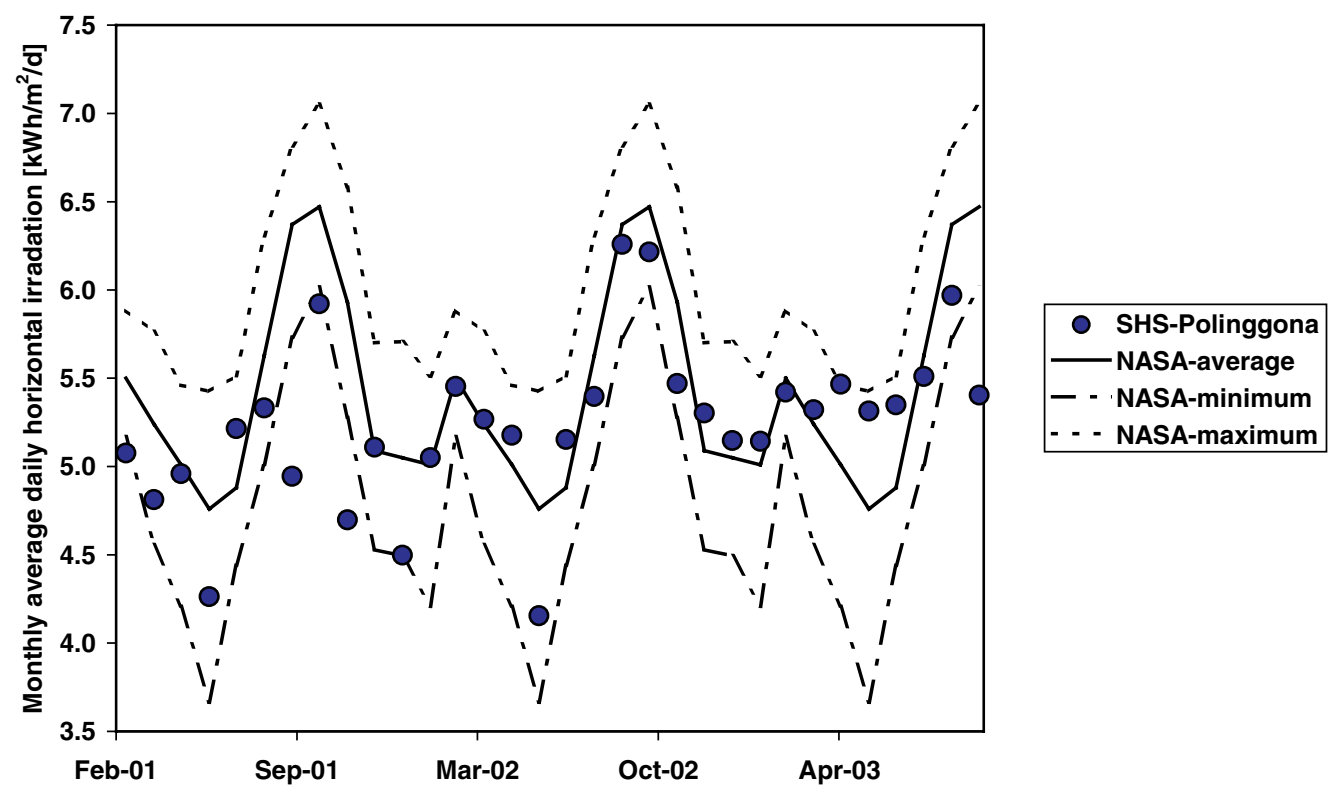

Figure 12. Calculated monthly average irradiation in Polinggona over the period March 2001 to October 2003, compared with NASA satellite-based climate data. For the satellite data, 10-year averages and 10-year extremes are presented 
large correction. Expected errors will become larger at higher latitudes. Future work is required to verify the procedure also for other locations, preferably further $\left(>30^{\circ}\right)$ from the equator.

The proposed method allows for determination of the absolute level of irradiation. However, the errors can be substantial and are in the same order of magnitude as with the use of historical data based on satellite data $(10-15 \%)$. Whenever the calculated irradiation figures can be compared or scaled with a short time series of locally measured data, the error in the absolute level of irradiation will be at about the same level as direct insolation measurements with a reference cell (5-10\%). The usefulness of this method depends on what is an acceptable error level. If an error of $15 \%$ is acceptable and monthly averages are sufficient, then it is much easier to use historical satellite data. If the error has to be $10 \%$ or less, or if daily insolation values are required, then it is worth spending the effort in calculating insolation with this method.

Soiling of the PV-modules reduces output and affects the calculated insolation figures. In case of gradual accumulation of dust on the modules, calculated insolation is overestimated before the moment with the highest module current in a year and underestimated afterwards. In practice, rain will often wash away part of the dust. If modules are not cleaned manually, part of the dust will stick and cause module output to decrease gradually over the years. One of the advantages of the presented method over direct measurements of insolation with a reference cell is that for a multi-year period, our method is less affected by soiling of the reference cell or PV-modules and long-term degradation of the solar cells. Each year a sort of calibration takes place, relating maximum module current to maximum clear sky irradiance. This renders our method insensitive for degradation of module output over the years.

Whenever a choice is possible, direct measurements of insolation are preferred over the presented method of constructing a time series of insolation based on PV-module currents. The above-mentioned advantage of insensitivity for long-term degradation does not weigh as much as the disadvantage of having to use a complex calculation method with a number of uncertainties.

\section{SUMMARY AND CONCLUSIONS}

A method to estimate daily irradiation data is presented here. It is based on the correlation of a number of measured PV-module currents and battery voltages of SHSs that are located within small distances from each other. Such a method is a useful tool in evaluation of the performance of these systems, as often, local irradiation data are not available.

Three different ways to validate the methodology to use PV-module currents to calculate insolation all come up with consistent outcomes. Comparison with 3 days of reference cell measurements and with satellite data suggests that the module current approach underestimates the insolation by 5 and $4 \%$, respectively. On the other hand, the 2 months of reference cell measurements in Polinggona show an overestimate of insolation by 1-3\%. These findings support an error estimate of $5-10 \%$ for the monthly averages in case there is time series of a few weeks or months of actual measurement with which the calculations can be compared. If such measurement series is missing, the estimated systematic error is 10 to $15 \%$, which is in the same order as the error in the monthly satellite data (10-17\%). It can be concluded that using PV-module currents of a number of nearby solar systems provides a means of obtaining reliable estimates of daily and monthly irradiation whenever actual measurements are absent or unreliable. Especially, when daily insolation data are required this method provides useful complementary information to the readily available satellite data that are limited to monthly averages.

\section{Acknowledgements}

This work was financed by an internal ECN grant in the framework of the ENGINE programme. Assistance with the field work was provided by BPPT in Indonesia in particular by Martin Djamin, Febrian Alyuswar and Yusak Lubis. We are grateful to Eddy Kantosa of BPPT-LSDE for providing insolation data from the World Bank logger in Polinggona. Comments of a number of reviewers have improved this article. In particular, we thank Teun Burgers of ECN and Jethro Betcke of University of Oldenburg in Germany. 


\section{REFERENCES}

1. Nieuwenhout FDJ, van Dijk A, van Dijk VAP, Hirsch D, Lasschuit PE, van Roekel G, Arriaza H, Hankins M, Sharma BD, Wade H. Experience with solar home systems in developing countries: a review. Progress in Photovoltaics: Research and Applications 2001; 9: 455-474.

2. Parodi O, Schweizer-Ries P, Preiser K, Wendl M. When night falls on Balde de Leyes - the success-story of an integrated approach in PV rural electrification. Proceedings of the 2 nd world conference and exhibition on photovoltaic solar energy conversion, Vienna 1998; 3068-3071.

3. Parodi O, Preiser K, Schweizer-Ries P. Balde de Leyes: the electrification of a remote village in Argentina. Proceedings of the ISES Utility Initiative for Africa, Midrand, RSA, 2000.

4. Reinders AHME, Pramusito Sudradjat A, van Dijk VAP, Mulyadi R, Turkenburg WC. Sukatani revisited: on the performance of nine-year-old solar home systems and street lighting systems in Indonesia. Renewable and Sustainable Energy Reviews 1999; 3(1): 1-47.

5. Dasuki AS, Djamin M, Lubis YA. The strategy of photovoltaic technology development in Indonesia. Renewable Energy 2001; 22(1-3): 321-326.

6. Djamin M, Alyuswar F, Sudradjat A, Nieuwenhout FDJ. Performance evaluation and analysis of solar home systems in Kolaka, South East Sulawesi, Indonesia. Proceedings of the ISES 2001 Solar World Congress, Adelaide; 1461-1465.

7. Nieuwenhout FDJ, Djamin M. Monitoring solar home systems in Indonesia. Proceedings of the conference PV in Europe-from PV Technology to Energy Solutions Conference and Exhibition, Rome, Italy, 2002; $1224-1227$.

8. NASA. Surface meteorology and Solar Energy database, Release 4 (http://eosweb.larc.nasa.gov/sse/); 2003.

9. Nieuwenhout Frans, van der Borg Nico, van Sark Wilfried, Turkenburg Wim. Estimating insolation based on PV module currents in a cluster of stand-alone solar systems: introduction of a new method. Solar Energy 2006; 80: $1220-1222$.

10. Sentry datalogger website. http://sentry.nl/

11. Duffie JA, Beckman WA. Solar Engineering of Thermal Processes (2nd edn). Wiley-Interscience: New York, USA, 1991. ISBN 0-471-51056-4.

12. Green MA. Solar Cells, Operating Principles, Technology and System Applications. University of New South Wales: Australia, 1998.

13. Townsend TU. A Method for Estimating the Long-Term Performance of Direct-Coupled Photovoltaic Systems. M.S. Thesis Mechanical Engineering, U. of Wisconsin-Madison, 1989.

14. Rigollier C, Bauer O, Wald L. On the clear sky model of the ESRA-European Solar Radiation Atlas-with respect to the Heliostat method. Solar Energy 2000; 68(1): 33-48.

15. Bourges G. Reconstitution des courbes de fréquence cumulées de l'irradiation solaire globale horaire reçue par use surface plane. In Report CEE 295-77-ESF, Vol. Tome II. Centre d'Energétique de l'Ecole Nationale Supérieure des: Mines de Paris: Paris, France, 1979.

16. Perrin de Brichambaut C, Vauge C. Le gisement solaire: evaluation de la ressource énergétique. Technique et documentation (Lavoisier): Paris, 1982.

17. Erbs DG, Klein SA, Duffie JA. Estimation of the Diffuse radiation fraction for hourly, daily and monthly-average global radiation. Solar Energy 1982; 28: 293-302.

18. PVSYST. A PV system design tool of the University of Geneva (http://www.unige.ch/cuepe/pvsyst/pvsyst/index.htm).

19. Solarc. Producer of the MacSolar SLM018c radiation measurement device http://www.solarc.de/ 